\title{
Spatial Analysis of the Degraded Forest Areas in Idmine Forest- Morocco Using Geoscience Capabilities
}

\author{
Said LAARIBYA ${ }^{1}$, Assmaa ALAOUI ${ }^{2}$, Sezgin AYAN ${ }^{3 *}$, Abdelkader BENABOU ${ }^{4}$ \\ ${ }^{1}$ Chouaib Doukkali University, Geography Department, El Jadida, MOROCCO \\ ${ }^{2}$ Ibn Zohr University - LBVRN, Biology Department, Agadir, MOROCCO \\ ${ }^{3}$ Kastamonu University, Faculty of Forestry, Silviculture Department, Kastamonu, TURKEY \\ ${ }^{4}$ Mohammed V University, Biology Department, Rabat, MOROCCO \\ *Corresponding Author: sezginayan@gmail.com
}

Received Date: 05.06.2020

Accepted Date: 20.11.2020

\section{Abstract}

Aim of study: The aim of the study is to present a diagnosis for the state of Argan forest degradation in Morocco through GIS and remote sensing utilizing Sentinel 2 satellite images of the year 2019 (dated 28/08/2019).

Area of study: The study was carried out in a forest commune in Idmine, South West Morocco, which is located in semi-arid bioclimatic region.

Material and methods: In the study, two methods were tested. These are; (i) the vegetation indices (VIs) [Normalized Difference Vegetation Index (NDVI), Normalized Difference Water Index (NDWI), SoilAdjusted Vegetation Index (SAVI), Brilliance Index (IB)] and their combination and (ii) the supervised classification and spectral analysis.

Main results: Two methods have given the same results (Kappa coefficient=90\%) to describe the state of forest degradation. Consequently, three classes pertaining to forest degradation within the study area were; low (34\%), medium (44\%) and critical degradation (22\%).

Highlights: This monitoring might help managers to create forest management plans and to evaluate the speed of deforestation and degradation.

Keywords: GIS, Remote Sensing, Vegetation Index, Degradation.

\section{Fas'ın Idmine Ormanı'ndaki Bozulmuş Orman Alanlarının Yerbilim Yeteneklerini Kullanarak Mekansal Analizi}

$\ddot{\mathbf{O} z}$

Çalışmanın Amacı: Çalışmanın amacı, 2019 yılının (28/08/2019 tarihli) Sentinel 2 uydu görüntülerini kullanarak CBS ve Uzaktan Algılama yoluyla orman bozulma durumu için bir tanı sunmaktır.

Çalışma Alanı: Çalışma, yarı kurak biyoklimatik bölgede bulunan Güney Batı Fas'taki Idmine orman komününde gerçekleştirilmiştir.

Materyal ve Yöntem: Bu çalışmada, iki yöntem denenmiştir. Bunlar; (i) Vejetasyon indisleri (VIs) [Normalize Fark Vejetasyon İndeksi (NDVI), Normalize Fark Su İndeksi (NDWI), Toprak-uyarlı Vejetasyon İndeksi (SAVI), Parlaklık İndeksi (IB)] ve bunların kombinasyonu ile (ii) Denetimli siniflandırma ve spektral analizdir.

Temel sonuçlar: Orman degradasyon durumunu tanımlamak için iki yöntem aynı sonuçları (Kappa katsayısı=\%90) vermiştir. Sonuç olarak, çalışma alanı içindeki orman degredasyonuna ilişkin üç sınıf; düşük (\%34), orta (\%44) ve kritik bozulma (\%22)'dır.

Araştırma Vurguları: Bu izleme, yöneticilerin orman yönetim planları oluşturmasına ve ormansılaşma ve orman degredasyonu hızını değerlendirmesine yardımcı olabilir.

Anahtar Kelimeler: CBS, Uzaktan Algılama, Vejetasyon Indeksi, Degradasyon 


\section{Introduction}

Morocco has very varied landforms: $70 \%$ of the country is mountainous while $30 \%$ is composed of plains, thanks to wide variety of climatic conditions as a result of its geographical situation (URL 1). Morocco's forest areas are rich and diverse, covering an area of around 9 million hectares, 5.8 million ha of which are forested (IFN, 1994). Protecting and sustainably managing Morocco's diverse and rich forest lands are a priori for the forest managers. The valuable Argan (Argania spinosa (L.) Skeels), Cork oak (Quercus suber L.), holm oak (Quercus ilex L.) and Saharan acacias (Acacia spp.) forest trees that hold nation's $63 \%$ of forested lands have been diminishing due to desertification caused by $90^{\prime}$ and 2000's droughts (URL 1). These forest lands contribute to the sustainable development of rural areas and play an important role in protecting the environment and combating desertification. However, forest ecosystems are subject to socioeconomic constraints linked to the precarious conditions of rural populations and to natural constraints linked mainly to the aridity of the climate and the sensitivity of the land to degradation (Laaribya et al., 2010; Laaribya et al., 2017; Laaribya \& Alaoui, 2017; Alaoui et al., 2020). These constraints translate into negative consequences at the local level. Using of remote sensing and GIS in forestry is a major tool for evaluating the state of Argan forest degradation with high spatial resolution satellite data (Hansen et al., 2008; Kinoshita et al., 2009; Cuenca et al., 2016; RomeroSanchez and Ponce-Hernandez, 2017). Romero-Sanchezand et al. (2017) reported that the criterion/indicators approach uses five criteria that relate to drivers of degradation, loss of ecosystem services and the need for sustainable management, unusual disturbances, protected functions, and carbon storage.

Many studies have been carried about forest degradation and cover change detection (Villa et al., 2009; Song et al., 2014; Haque \& Basak, 2017; Romero-Sanchez \& PonceHernandez, 2017). Moreover, the vegetation indices (VIs) are very effective to assess the performance of the spatial coverage (Lyon et al., 1998; Huete et al., 2002; Schultz et al.,
2016; Morton et al. 2006). Some of these studies were based on Normalized Difference Vegetation Index (NDVI) differencing Change Detection (Ochego, 2003; Lea et al., 2004), Soil-Adjusted Vegetation Index (SAVI) (Yang et al., 2003), Tasseled Cap (Lyon et al., 1998) and Subpixel classification (Wang, 2016). Tasseled Cap Greenness, Wetness and Brightness are the three plans of the Tasseled cap index that give optimized results of soil moisture and vegetation (Baumann et al., 2014). In literature, there are many techniques to calculate change detection: image differencing (Afify, 2011), vegetation index differencing (Sahebjalal \& Dashtekian, 2013), and others advanced methods (Torahi \& Rai, 2011; Adedeji \& Adeofun, 2014; Onojeghuo \& Onojeghuo, 2015) are developed to meet the real need for complex forest changes.

Anxious to preserve and develop the forest heritage and wealth in a sustainable manner and taking into account the current socioeconomic and ecological issues, this work aims to diagnose the situation of forest areas in Idmin forest commune, and make a value judgment on the regressive dynamics of these species, which is located at the heart of an Argan biosphere in Morocco, according to a field and cartographic approach based on GIS and remote sensing. The results obtained will also make it possible to compare between the two main approaches used in this study: Index-based classification and supervised classifications. The objective of the study is to present a diagnosis for the state of Argan forest degradation using geoscience capabilities through GIS and remote sensing approach.

\section{Material and Methods \\ Study Area}

The study area is located at the forest commune of Idmine with an area of $145 \mathrm{~km}^{2}$. It is a forest commune located in the heart of an Argan biosphere reserve in Morocco (Laaribya et al., 2017). Recognising its ecological value and local economic importance, the Argan region was declared a UNESCO Biosphere Reserve in 1998.

Given the biogeographical position of the study area (proximity to the Atlantic Ocean), the reliefs of the high altitudes are relatively 
cool but strongly influenced by the hot and dry winds from the South and Southeast.

The relief of the study area covers: the southwestern border of the High Atlas Mountains and part of the western half of the what plain. The altitudes vary between $260 \mathrm{~m}$ to $1050 \mathrm{~m}$. With regard to the slope of the terrain, the synthesis of the topographic data showed that the slopes were relatively more pronounced in the majority of the area (Figure 1, 2). Mountain physiographic units dominated the area.

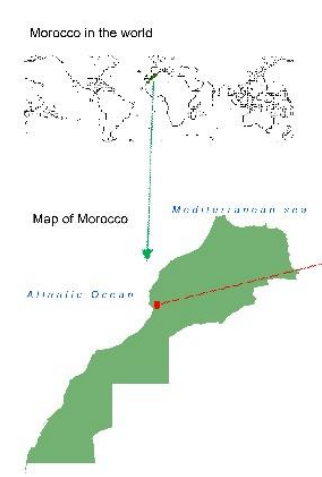

Figure 1. Study areas within Rural administrative division (Douars)

The study area is in a semi-arid bioclimate zone. According to the climatic data available for the area, the average annual precipitation varies between 224 and $533 \mathrm{~mm}$ with a very significant variability during the year. The seasonal rainfall regime is: Winter - AutumnSpring-Summer, where around $49 \%$ of annual rainfall is collected in winter. The dry season lasts between 5 to 10 months depending on the season. The natural and dominant forest formations are formed by the following main forest species; homoculture Argan tree (Argania spinosa (L.) Skeels) at low altitudes, the tetraclinis (Tetraclinis articulate (Vahl) Mast.) often in mixture with the Argan tree and Holm oak (Quercus rotundifolia Lam. or $Q$. ilex $\mathrm{L}$.) at high altitudes and the secondary species that accompany them; Oleaster (Olea europaea L.), Carob tree (Ceratonia siliqua L.), Mastic tree (Pistacia lentiscus L.), Genista ferox Poir and Genista tricuspidata Desf., Lavender (Lavandula multifida L. and L. dentata L.).

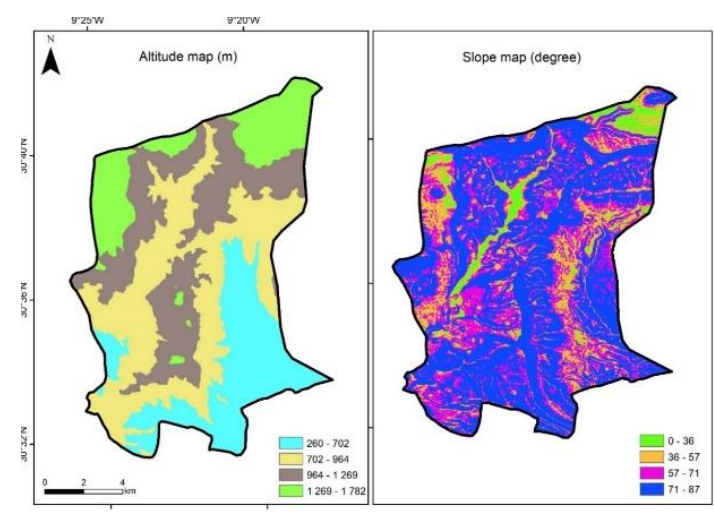

Figure 2. Digital altitude and slope maps of the study area (made from Shuttle Radar Topography Mission)

\section{Approaches Adopted: Cartograpy, Geographic Information System (GIS) and Remote Sensing}

A qualitative approach using GIS and space remote sensing using Sentinel-2 satellite imagery was employed. To do this, we used several approaches and instruments.

In addition to the mapping (GIS) of forest species in this study area, the approach focused on the analysis of the main vegetation and soil monitoring indices through the analysis of the following best known indices such as Normalized Difference Vegetation Index (NDVI), Normalized Difference Water Index (NDWI), Soil-Adjusted Vegetation Index (SAVI) and Brilliance Index (IB). Indices are combinations of surface reflectance at two or more wavelengths designed to highlight a particular property of vegetation. They are derived using the reflectance properties of vegetation. Each of the indices is designed to accentuate a particular vegetation property. In fact, these indices are part of the processing methods known as multispectral transformations. They consist in converting the luminances' measured at the level of the satellite sensor into quantities having a significance in the field of the environment. The Sentinel-2 (Sentinel 2 satellite images of the year 2019 (dated 28/08/2019)) satellite imagery with a resolution of 10 meters served as the basis for the study. Based on the multispectral nature of the satellite data, the indices and the supervised classification used make it possible to identify the dynamics of the degrading situation of the forest areas of the 
study area, Commune of Idmine (Figure 3, 4). Spectral reflectance curve shows the relationship between electromagnetic spectrum and the associated percent reflectance for any given material (Figure 3).

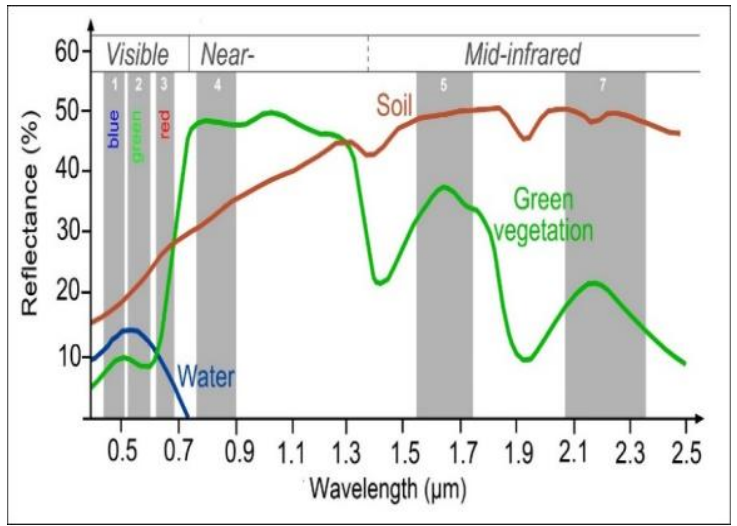

Figure 3. Spectral reflectance curve (Siegmund \& Menz, 2005) (Sentinel Sensor)

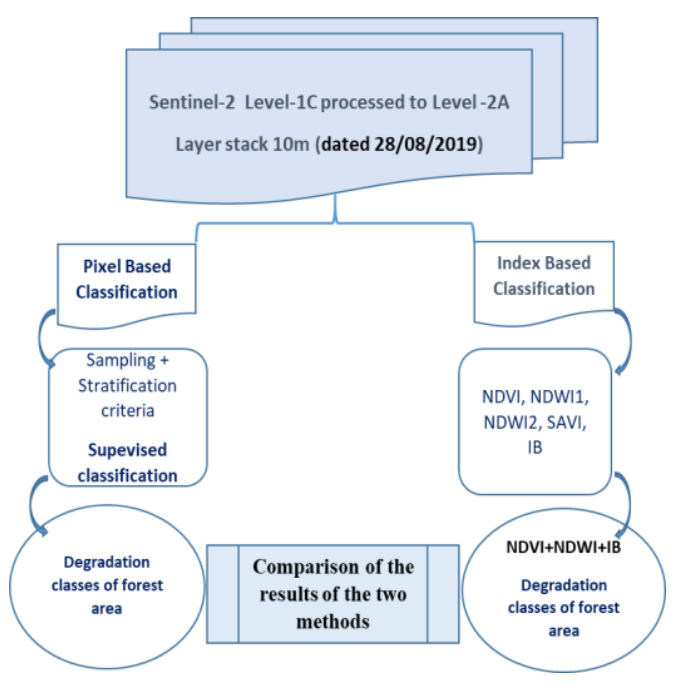

Figure 4. Work flow to describe the process

\section{Satellite Image Description}

Sentinel-2 satellite images were used in our study. It was downloaded from the Copernicus Open Access Hub (previously known as Sentinels Scientific Data Hub). The product Level 1C includes radiometric and geometric corrections with sub-pixel accuracy. These data were processed to a Level-2A (atmospherically corrected). Data product using Sentinel-2 Toolbox (Sentinel Application Platform, SNAP) with an integrated Sen2cor processor (Sentinel to Correction). All Level-2A data were pre- processed to obtain a layer stack of 10 spectral bands, resampled to the resolution of $10 \mathrm{~m}$ for all bands.

\section{a) Index-base Classification}

Five different indexes used for land and forest mapping were used in this study, Normalized Difference Vegetation Index (NDVI), Normalized Difference Water Index and vegetation stress (NDWI1 and 2), Soiladjusted Vegetation Index (SAVI), Brilliance Index (IB). All of the indexes have been used for classifying different land forest covers (Equations 1 to 5)

Where NIR represents the near infrared band, SWIR the short wave infrared spectral range, $\mathrm{R}$ the red band, and $\mathrm{Gr}$ is the green band. All the indexes were calculated for the imagery Sentinel-2 data.

- Normalized Difference Vegetation Index (NDVI):

The Normalized Difference Vegetation Index (NDVI) (Tucker, 1979) is the most commonly used vegetation index for observe greenery globally (Equation 1).

$$
N D V I=\frac{N I R-R}{N I R+R}
$$

- Normalized Difference Water Index (NDWI):

Normalize Difference Water Index (NDWI) (Gao, 1996) is use for the water bodies analysis (2) and the vegetation stress (3) and enhance their presence in remotelysensed digital imagery (McFeeters, 1996). The NDWI can enhance water information efficiently in most cases. The NDWI products can be used in conjunction with NDVI change products to assess context of apparent change areas (Equation 2 and 3).

$$
N D W I=\frac{G r-N I R}{G r+N I R}
$$




$$
N D W I=\frac{N I R-S W I R}{N I R+S W I R}
$$

\section{- Soil - Adjusted Vegetation Index (SAVI)}

This index is a transformation technique that minimizes soil brightness influences from spectral VIs involving red and near-infrared (NIR) wavelengths (Equations 4) (Huete, 1988).

$$
S A V I=\frac{N I R-\operatorname{Red}}{N I R+\operatorname{Red}+L}(1+L) \text { with } L=0,5
$$

Where L is a canopy background adjustment factor. An $\mathrm{L}$ value of 0.5 in reflectance space was found to minimize soil brightness variations and eliminate the need for additional calibration for different soils.

- Brilliance Index (IB) as Equation 5.

$$
I B=\operatorname{Root}\left(N I R^{2}+R^{2}\right)
$$

In addition to colour, among other things, the spectral properties of a soil are intimately linked to the variation in its gloss (Bannari et al., 1996).

In order to classify the degraded forest area, the NDVI products was used in conjunction with NDVI and IB to assess and classify of space change forest areas. Indeed, this combination was used: NDVI+NDWI+IB. Although all the 5 different indexes were used in the study to diagnose and to explain the degraded forests.

\section{b) Supervised Classification (Pixel based classification)}

In supervised classification, analyst identified the above mentioned classes and a maximum likelihood classification algorithm was used. The distribution according to a random sampling of the Points was used in our
Supervised classification (Figure 5). This involves classifying the different characteristics of the image in question, using optical interpretation and good knowledge of the terrain to identify homogeneous spaces of pixels, which represent classes of surfaces. Indeed, the digital classification of images uses the spectral information contained in the values of one or more spectral bands to classify each pixel individually (spectral groupings).

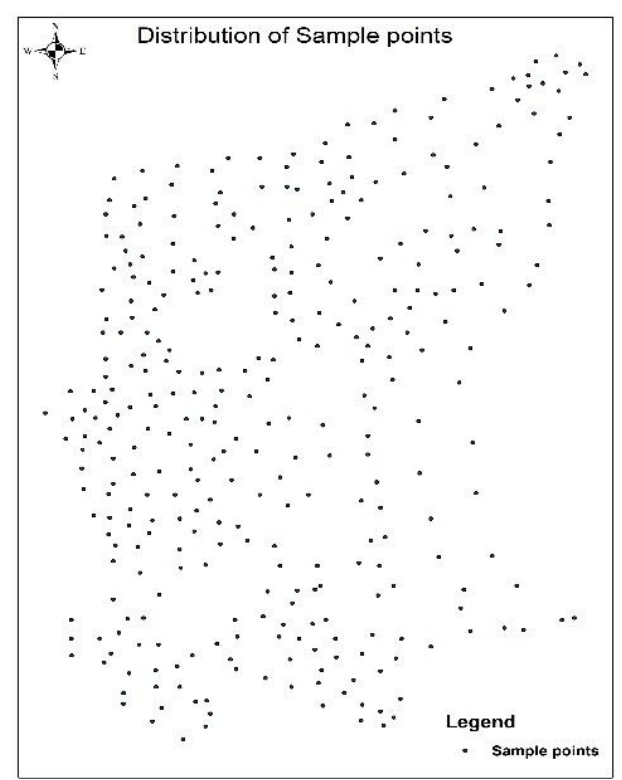

Figure 5. Distribution of sampling point for supervised classification

The goal is to assign a class to each of the pixels of an image taking into account the situation of the forest areas studied. Three classes are described in the Table 1. The classification is mainly based on the species composition in the forest study area, the density (number of trees/hectare) and condition of the forest stands on the ground (Anthropic impact of human activity). Indeed, three classes are specified in the table (Table $1)$. 
Table 1. Criteria of classification approach

\begin{tabular}{|c|c|c|c|}
\hline Criteria/Class names & Species composition & Density/Cover & Anthropic impact \\
\hline $\begin{array}{c}\text { Level of degradation } \\
1 \text { (Low) }\end{array}$ & \multirow{3}{*}{$\begin{array}{c}\text { Name of the forest } \\
\text { species }\end{array}$} & $\begin{array}{c}\text { High density/cover } \\
\geq 66 \%\end{array}$ & $\begin{array}{l}\text { Low impact of human } \\
\text { activity }\end{array}$ \\
\hline $\begin{array}{c}\text { Level of degradation } \\
2 \text { (Average) }\end{array}$ & & $\begin{array}{l}\text { Medium density/cover } \\
(33 \% \leq \mathrm{d}<66 \%)\end{array}$ & $\begin{array}{l}\text { Medium impact of } \\
\text { human activity }\end{array}$ \\
\hline $\begin{array}{c}\text { Level of degradation } \\
3 \text { (High) }\end{array}$ & & $\begin{array}{c}\text { Low density/cover } \\
(<33 \%)\end{array}$ & $\begin{array}{l}\text { High impact of human } \\
\text { activity }\end{array}$ \\
\hline
\end{tabular}

\section{Results}

Remote sensing data are primary sources for analysing the environmental processes in different scales. These data are used to detect land cover changes. Remote sensing by Sentinel 2 data used in this study are very useful for visualization classification of the analysis area.

\section{Index-based Classification}

From the results of the analysis, it was concluded that the NDVI values are between -0.12 and +0.49 , the negative values corresponding to surfaces other than plant cover, such as water for which the reflectance in red is greater than that of the near infrared. For bare soils, the NDVI in the area has values close to zero. Vegetation formations, on the other hand, have positive NDVI values, between 0.1 and 0.49 . The values found are generally low, corresponding to the least dense covers. Indeed, in the area more than 0.6 is needed for dense forest cover detection. Low density and degraded forest area might have caused this (Figure 6).

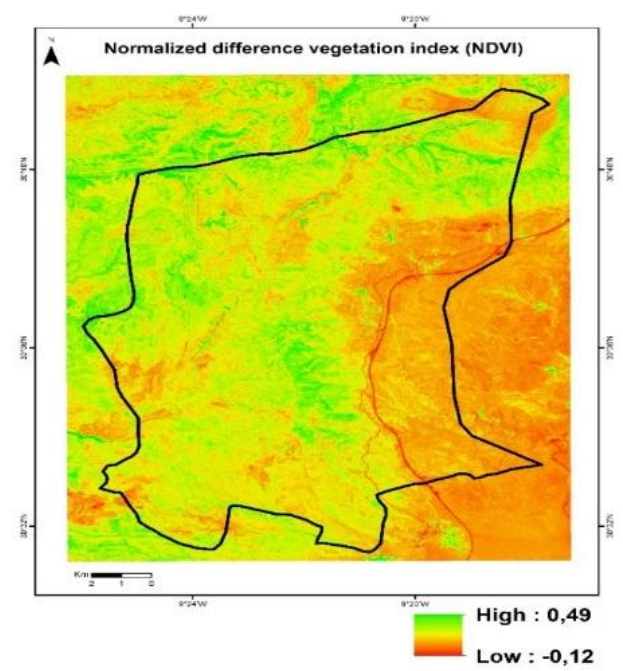

Figure 6. Normalized difference vegetation index (NDVI)
NDWI makes it possible to detect when plants are in a state of water stress and are therefore very convenient for monitoring vegetation in the study area (semi dry areas).

Indeed, this Index (NDWI) is used for the water bodies analysis. The NDWI has been used to delimit the elements of free water and improve their presence in digital remote sensing imagery. It provided turbidity estimates for water bodies using remotely sensed digital data (Figure 7).

The NDWI 1 relating to the calculated water stress presented a low between the values written between -0.43 and 0.043 , while the NDWI2 relating to the stress of the vegetation was between -0.18 and 0.2 . The results obtained allowed us to conclude that the study area which was located in a semiarid bio climate, suffered from a lack of wetlands, and the forest areas were in a state of water stress (Figure 7). The NDWI products can be used in conjunction with NDVI to assess the land cover changes.

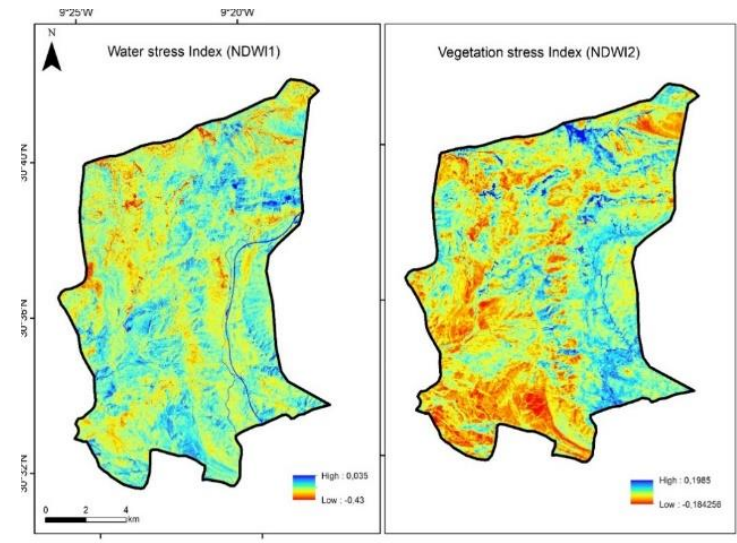

Figure 7. Normalized difference water index (NDWI1 and NDWI2)

This index outputs varied between -0.08 and 0.67 . Indeed, SAVI is a vegetation index attempting to minimize soil brightness 
influences using a soil-brightness correction factor (Figure 8).

The Brilliance (brightness) Index (IB) index is therefore sensitive to the brightness of the soil and made it possible to highlight that the majority of the forest area was clear. From the results obtained, we can notice that this index presented important values in the study areas where NDVI was low. The IB index represents the average of the image brightness (Figure 8). The clarification of course corresponded to less plant cover area, and often gave rise to a diagnosis of degradation in the state of the environment. The interpretation of this index is not always easy.

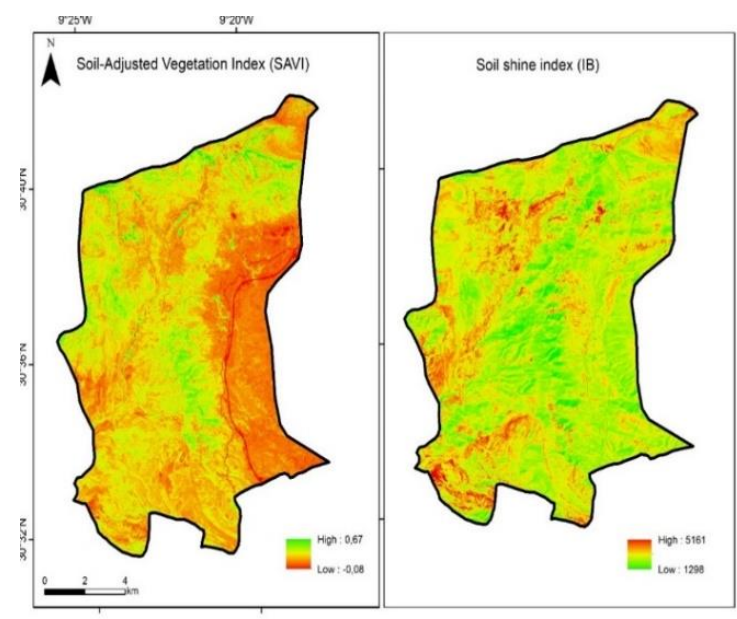

Figure 8. Soil - adjusted vegetation index (SAVI) and brilliance index (IB)

From the analyses of the different indexes and in order to classify the degraded forest area, the NDVI products were used in conjunction with NDVI and IB to assess and classify the forest change status areas. Indeed, this combination NDVI+NDWI+IB gave us three degradation classes (Figure 9): Low, Average and Critically degraded forest area.

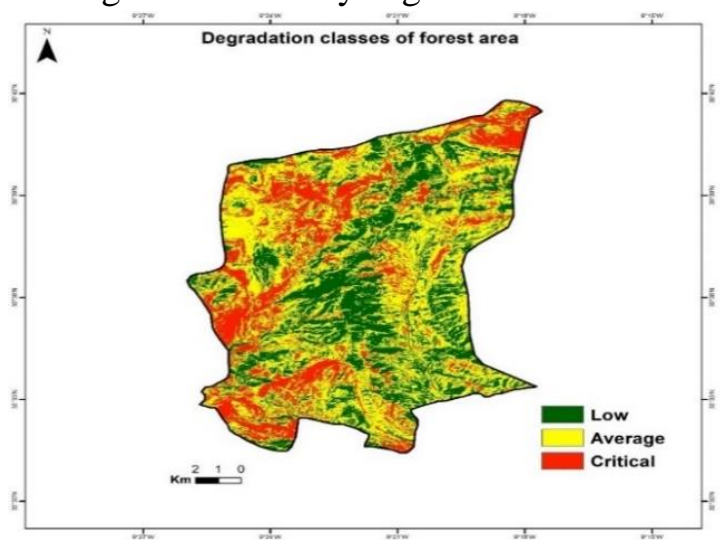

Figure 9. Classification of forest area (combination NDVI, NDWI and IB)

Digital classification from satellite image data is frequently used because of the less time consuming and the source data that provide a high temporal resolution. In this study, supervised classifications was performed. The results from the classification were presented in figure 10.

This supervised classification needed a good knowledge of the field study by a lot of visit. With different stratification criteria (density/forest cover, forest species, and human pressure), it was more convenient to separate different classes of degradation areas in this forest study area (Table 2). The supervised classification gave the same results as the first Index-based Classification (Figure $10)$.

Table 2. Degradation classes of forest area (Result of the supervised classification)

\begin{tabular}{ccccc}
\hline Class & $\begin{array}{c}\text { Degraded } \\
\text { situation }\end{array}$ & Forest species & $\begin{array}{c}\text { Surface } \\
(\%)\end{array}$ & Criteria \\
\hline 1 & Low & $\begin{array}{c}\text { Argania spinosa }+ \text { Tetraclinus } \\
\text { articulate }\end{array}$ & 34 & $\begin{array}{c}\text { Density/cover }(\geq 66 \%), \\
\text { and Low human activity }\end{array}$ \\
\hline 2 & Average & $\begin{array}{c}\text { Argania spinosa / Mixed of Argania } \\
\text { spinosa }+ \text { Tetraclinus articulate }\end{array}$ & 44 & $\begin{array}{c}\text { Density/cover }(33 \% \leq d<66 \%), \\
\text { and Medium human activity }\end{array}$ \\
\hline 3 & Critical & $\begin{array}{c}\text { Mixed of Argania spinosa }+ \text { Quercus } \\
\text { ilex } \\
\text { Uncovered and mattoral land }\end{array}$ & 22 & $\begin{array}{c}\text { Density/cover }(<33 \%), \\
\text { and Hight human activity }\end{array}$ \\
\hline
\end{tabular}




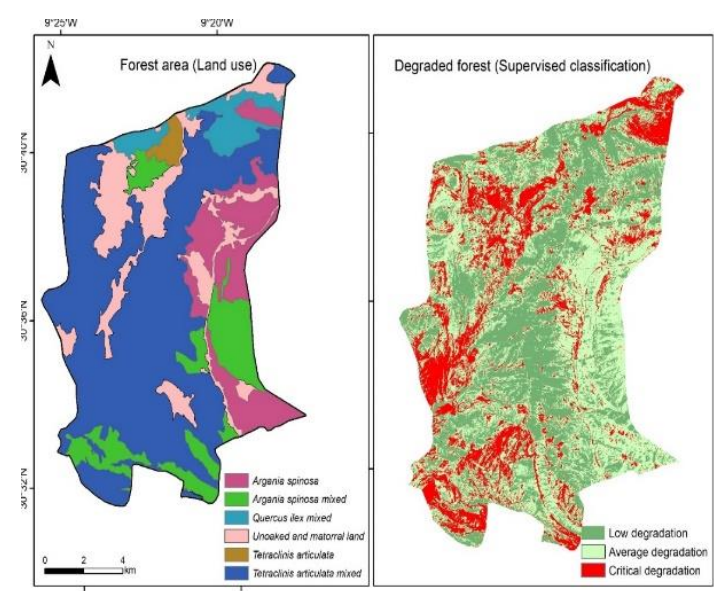

Figure 10. Degraded classification of forest area (Supervised classification)

\section{Discussion and Conclusion}

The study area, forest Idmine commune, has great ecological potential and plays an important role in protection and capital socioeconomic development since they provide a wide variety of wood and non-wood products, constitute a space under the forest and offer other economic, socio-cultural and environmental services.

Argan forest degradation has become a serious problem, especially in Morocco. Among other impacts, it was an urgent need to measure and analyse it, in order to design action to reverse the process.

The normalized difference vegetation index (NDVI) and all others indictors which were estimated through analysis of Sentinel 2 satellite images to give an indication of "the situation of argan forest areas". The premise is that NDVI is an indicator of vegetation health, because degradation of ecosystem vegetation, or a decrease in green, would be reflected in a decrease in NDVI value. In our study, the NDVI alone did not give good results. Low density and degraded forest area might have caused this. According to Ghebrezgabher et al. (2016), the NDVI is the most used index in vegetation studies. NDVI used for monitoring the forest degradation and deforestation in India by Kumar et al. (2010). In addition, Xue \& Su (2017) emphasized that NDVI also gives an overview of the quality and density of vegetation. For evaluating the potential for monitoring forest change in Sudan, Nori et al. (2008) integrated NDVI and SAVI. The SAVI is a modification of the NDVI in order to correct the influence of the soil brightness (Huete, 1988). Healey et al. (2005) used tasseled cap for the detection of forest disturbances in Russia and the Unites States.

Remote sensing data are primary sources for analyzing environmental processes in different scales. The approach adopted has shown that the two methods used, based on the exploitation of available satellite images of Sentinel-2, gave the same results as the calculation and the combination of the indices (NDVI, NDWI, SAVI and IB) and the supervised classification. Indeed, the fact of constructing synthetic indicators via the analyses of satellite images made it possible to a large extent. Kappa was calculated how is an accuracy indicator to describe the state of degradation of forest areas. It is a measure of how the classification results compare to values assigned by chance (Agreement between the classified image and the reference image "google earth imagery". The database from the Forest National Inventory (Morocco) was used also) (Accuracy rate $=90 \%$ ).

The results obtained from the SAVI index confirmed those obtained by the NDVI and NDWI. This is often used in arid regions where vegetative cover is low (McFeeters, 1996).

Briefly as consequently, NDVI, NDWI, SAVI, IP indexes were used in the study and degraded forest maps were made with the data obtained from these indexers. In addition, degraded forest maps were made with supervised classification according to a random sampling. The study area highlighted with the percentages of degraded areas according to three classes of the degradation; low degradation (34\%), medium degradation $(44 \%)$ and a third class where degradation was critical (22\%). It is also necessary to point out the impact of human pressures on the forest area studied. The result confirms the state of degraded situation in forest Moroccan area and especially in the argan forest (Laaribya et al., 2017). However, the scale of the intensive degradation of forest resources (regression in favor of crops and urbanization, dedensification of the cover, etc.) and the overexploitation of water resources threaten the sustainability of development and urge the public authorities to take the necessary provisions necessary to reverse the 
deterioration trends in the study area and in all argan forest in Morocco.

\section{Ethics Committee Approval N/A}

\section{Peer-review}

Externally peer-reviewed.

\section{Author Contributions}

Conceptualization: $\quad$ S.L., $\quad$ A.A.; Investigation: S.L., A.A., S.A., A.B.; Material and Methodology: S.L., A.B.; Supervision: S.L., S.A.; Visualization: S.L., A.A., S.A., A.B.; Writing-Original Draft: S.L., S.A; Writing-review \& Editing: S.L., A.A., S.A., A.B.; Other: All authors have read and agreed to the published version of manuscript.

\section{Conflict of Interest}

The authors have no conflicts of interest to declare.

\section{Funding}

The authors declared that this study has received no financial support.

\section{References}

Adedeji, O.H. \& Adeofun, C.O. (2014). Spatial pattern of land cover change using Remotely Sensed Imagery and GIS: A Case study of Omo-Shasha-Oluwa Forest Reserve, SW Nigeria (1986-2002). Journal of Geographic Information System, 6(04), 375-385. https://doi.org/10.4236/jgis.2014.64033.

Afify, H.A. (2011). Evaluation of change detection techniques for monitoring land-cover changes: A case study in New Burg El-Arab Area. Alexandria Engineering Journal, 50(2), 187195. https://doi.org/10.1016/j.aej.2011.06.001.

Alaoui, A., Laaribya, S. \& Ayan, S. (2020). The evolution of the forest cover with the effect of anthropic pressure (The Case Study of Sehoul Cork-Oak Forest in Morocco, North Atlantic). Kastamonu University Journal of Forestry Faculty, 20(1), 62-73.

Bannari, A., Huete, A.R., Morin, D. \& Zagolski, F. (1996). Effets de la couleur et de la brillance des sols sur les indices de végétation. International Journal of Remote Sensing, 17(10), 1885-1906.

Baumann, M., Ozdogan, M., Wolter, P.T., Krylov, A., Vladimirova, N. \& Radeloff, V.C. (2014). Landsat remote sensing of forest windfall disturbance. Remote Sensing of Environment,
143, 171-179.

https://doi.org/10.1016/j.rse.2013.12.020.

Cuenca, P., Arriagada, R. \& Echeverría, C. (2016). How much deforestation do protected areas avoid in Tropical Andean Landscapes? Environmental Science \& Policy, 56, 56-66. https://doi.org/10.1016/j.envsci.2015.10.014.

Gao, B. (1996). NDWI - a normalized difference water index for remote sensing of vegetation liquid water from space. Remote Sensing of Environment, 58(3), 257-266, Dec.

Ghebrezgabher, M. G., Yang, T., Yang, X., Wang, X. \& Khan, M. (2016). Extracting and analysing forest and woodland cover change in Eritrea based on Landsat data using supervised classification. The Egyptian Journal of Remote Sensing and Space Science, 19(1), 37-47. https://doi.org/10.1016/j.ejrs.2015.09.002.

Hansen, M. C., Roy, D. P., Lindquist, E., Adusei, B., Justice, C.O. \& Altstatt, A. (2008). A method for integrating MODIS and Landsat data for systematic monitoring of forest cover and change in the Congo Basin. Remote Sensing of Environment, 112 (5), 2495-2513. https://doi.org/10.1016/j.rse.2007.11.012

Haque, M. I. \& Basak, R. (2017). Land cover change detection using GIS and Remote Sensing Techniques: A spatio-temporal study on Tanguar Haor, Sunamganj, Bangladesh. The Egyptian Journal of Remote Sensing and Space Science, 20(2), 251-263. https://doi.org/10.1016/j.ejrs.2016.12.003

Healey, S. P., Cohen, W. B., Zhiqiang, Y. \& Krankina, O. N. (2005). Comparison of Tasseled Cap-Based Landsat data structures for use in forest disturbance detection. Remote Sensing of Environment, 97(3), 301-310. https://doi.org/10.1016/j.rse.2005.05.009.

Huete, A., Didan, K., Miura, T., Rodriguez, E.P., Gao, X. \& Ferreira, L.G, (2002). Overview of the radiometric and biophysical performance of the MODIS vegetation indices. Remote Sensing of Environment, 83(1-2), 195-213. https://doi.org/10.1016/S00344257(02)00096-2.

Huete, A. R. (1988). A Soil-Adjusted Vegetation Index (SAVI). Remote Sensing of Environment, 25, 295-309. https://doi.org/10.1016/0034-4257(88)90106$\mathrm{X}$

IFN, (1994). Inventaire forestier National Département des eaux et forêts Maroc.

Khalile, L., Kaoukaya, H., Lahlaoi, H. \& Rhinane, H. (2015). Monitoring deforestation and forest degradation in Benslimane Forest (Morocco) using Landsat time series, November 2015, Conference: 4th International Geosciences \& Geomatics Conference, 23 $3^{\text {rd }} 25^{\text {th }}$ November 
2015, Manama, Bahrain.

Kinoshita, T., Inoue, K., Iwao, K., Kagemoto, H. \& Yamagata, Y. (2009). A spatial evaluation of forest biomass usage using GIS. Applied Energy, 86(1), 1-8. https://doi.org/10.1016/j.apenergy.2008.03.01 7

Kumar, P., Rani, M., Pandey, P.C., Majumdar, A. \& Nathawat, M.S. (2010). Monitoring of deforestation and forest degradation using Remote Sensing and GIS: A case study of Ranchi in Jharkhand (India). Report and Opinion, 2 (4), 14-20.

Laaribya, S. \& Alaoui, A. (2017). Rural women and the forest issues preservation - Case study, Morocco. Biological Diversity and Conservation, 10/2 (S2), 8-15.

Laaribya, S., Alaoui, A. \& Gmira, N. (2017). The Moroccan forest and sustainable development case of the argan tree (Argania spinosa (L.) Skeels) in Morocco, Biological Diversity and Conservation. 10/2 (S2), 1-7.

Laaribya, S., Najib, G. \& Assmaa, A. (2010). Towards a coordinated development of the forest in Maamora (Morocco), Kastamonu Univ., Journal of Forestry Faculty, 10(2), 172179.

Lea, R., Blodgett, C., Diamond, D. \& Schanta, M. (2004). Using the tasselled cap transformation to identify change in the Missouri Ozark Forests. Proceedings of the ASPRS Fall Conference Images to Decisions: Remote Sensing Foundations for GIS Applications, 112.

Lyon, J. G., Yuan, D., Lunetta, R.S. \& Elvidge, C.D. (1998). A change detection experiment using vegetation indices. Photogrammetric Engineering and Remote Sensing, 64(2), 143150.

McFeeters, S. K. (1996). The use of the normalized difference water index (NDWI) in the delineation of open water features. International Journal of Remote Sensing, 17(7), 1425-1432.

Morton, D.C., DeFries, R.S., Shimabukuro, Y.E., Anderson, L.O., Arai, E., del Bon EspiritoSanto, F., Freitas, R. \& Morisette, J.T. (2006). Cropland expansion changes deforestation dynamics in the Southern Brazilian Amazon. Proceedings of the National Academy of Sciences, 103(39), 14637-14641. https://doi.org/10.1073/pnas.0606377103

Nori, W., Elsidding, E.N. \& Niemeyer, I. (2008). Detection of land cover changes using MultiTemporal Satellite Imagery. The International Archives of the Photogrammetry, Remote Sensing and Spatial Information Sciences, 37(7), 947-951.
Ochego, H. (2003). Application of remote sensing in deforestation monitoring: A case study of the Aberdares (Kenya). 2 $2^{\text {nd }}$ FIG Regional Conference, Marrakech, Morocco, 2-5 December 2003, 1-10.

Onojeghuo, A.O, \& Onojeghuo, A.R. (2015). Dynamics of forest landscape transition across protected areas in the Niger Delta from 1986 to 2014. Journal of Geoscience and Environment Protection, 3(7), 1.

Romero-Sanchez, M.E. \& Ponce-Hernandez, R. (2017). Assessing and monitoring forest degradation in a deciduous tropical forest in Mexico via remote sensing indicators. Forests, 8(9), 302. https://doi.org/10.3390/f8090302.

Sahebjalal, E. \& Dashtekian, K. (2013). Analysis of land use-land covers changes using Normalized Difference Vegetation Index (NDVI) differencing and classification methods. African Journal of Agricultural Research, 8(37), 4614-4622.

Schultz, M., Clevers, J.G., Carter, S., Verbesselt, J., Avitabile, V., Quang, H.V. \& Herold, M. (2016). Performance of vegetation indices from Landsat time series in deforestation monitoring. International Journal of Applied Earth Observation and Geoinformation, 52, 318-327. https://doi.org/10.1016/j.jag.2016.06.020

Siegmund, A. \& Menz, G. (2005). Fernes nah gebracht -Satelliten- und Luftbildeinsatz zur Analyse von Umweltveränderungen im Geographieunterricht. In: Geographie \& Schule, 27. Jg., H. 154, 2-10.

Song, X.P., Huang, C., Sexton, J.O., Channan, S. \& Townshend, J.R. (2014). Annual detection of forest cover loss using time series satellite measurements of percent tree cover. Remote Sensing, 6(9), 8878-8903. https://doi.org/10.3390/rs6098878.

Torahi, A.A. \& Rai, S.C. (2011). Land cover classification and forest change analysis, using satellite imagery - A case study in Dehdez Area of Zagros Mountain in Iran. Journal of Geographic Information System, 3(1), 1-11. https://doi.org/10.4236/jgis.2011.31001

Tucker, C.J. (1979). Red and photographic infrared linear combinations for monitoring vegetation, Remote Sensing of Environment, 8 (2), 127-150.

URL 1. FAO (Forest and Agricultural Organization of the United States), Forests and the forestry sector: Morocco, http://www.fao.org/forestry/country/57478/en/ mar/, Access Date: 21.04.2020.

Villa, P., Lechi, G. \& Gomarasca, M.A. (2009). Multivariate differencing techniques for land cover change detection: The normalized 
difference reflectance approach. In: Geoscience and Remote Sensing, In-Tech., 277-300. https://doi.org/10.5772/8312

Wang, T. (2016). Vegetation NDVI change and its relationship with climate change and human activities in Yulin, Shaanxi Province of China. Journal of Geoscience and Environment Protection, 4, 28-40.

https://doi.org/10.4236/gep.2016.410002.

Xue, J. \& Su, B. (2017). Significant remote sensing vegetation indices: A review of developments and applications. Journal of Sensors, 1-17.

https://doi.org/10.1155/2017/1353691.

Yang, L., Xian, G., Klaver, J. M. \& Deal, B. (2003). Urban land-cover change detection through sub-pixel imperviousness mapping using remotely sensed data. Photogrammetric Engineering \& Remote Sensing, 69(9), 10031010.

https://doi.org/10.14358/PERS.69.9.1003 